\title{
Solubilization of Insulin Binding and Degrading Activity from Guinea Pig Kidneys
}

\author{
M. Kasuga, T. Tsushima, Y. Akanuma, and K. Kosaka \\ Third Department of Internal Medicine, Faculty of Medicine, University of Tokyo, Hongo, Tokyo, Japan
}

Summary. Insulin binding and degrading activities were solubilized by a nonionic detergent. Triton X100 , from guinea pig kidney particulate fractions $(100,000 \times \mathrm{g}$ pellet $)$. The solubilized insulin binding activity appeared as a single peak on Sepharose $6 \mathrm{~B}$ gel filtration with a Stokes radius of $73 \AA$. The $\mathrm{pI}$ of the solubilized insulin binding activity determined by flat-bed isoelectric focusing was 5.6. On the other hand, the Stokes radius of the solubilized molecule with insulin degrading activity was $54 \AA$ by the same column with a pI of 5.2. More than $98 \%$ of the insulin binding activity could be adsorbed to a column of concanavalin A-agarose, while about $94 \%$ of the insulin degrading activity could not be adsorbed to this column. These results strongly suggest that the macromolecule for the insulin binding activity is not identical to that for the insulin degrading activity.

Key words: Guinea pig kidney, insulin binding and degrading activity, solubilization, gel filtration, isoelectric focusing, concanavalin A-agarose affinity chromatography.

The initial step in the biological action of insulin involves binding to a specific receptor located on the plasma membrane of the target tissue cells [1]. Specific binding sites with high affinity for insulin have been identified in membrane fractions obtained from many types of tissue, including liver [2, 3], fat $[4,5]$ and placenta [6]. The specific binding sites for insulin have also been isolated and solubilized from liver membrane fractions [7], human placental cell membrane $[8,9]$ and avian erythrocyte membrane [10].

It has been reported that various guinea pig tissues, especially kidney, bind higher amounts of por- cine insulin than tissues of other animals [11]. In the present study, we have solubilized the insulin binding activity of guinea pig kidney, and studied some of its properties.

Generally many tissues have insulin degrading activity in association with insulin binding activity. The relation between the activities is controversial $[12,13]$. Insulin has been shown to be degraded by rat kidney cell membranes [14]. In the present study, we have therefore also solubilized the insulin degrading activity from the guinea pig kidney membrane fractions and examined its relationship to the solubilized binding activity.

\section{Materials and Methods}

\section{Hormones}

Crystalline porcine zinc insulin $(25.4 \mathrm{U} / \mathrm{mg})$ was a gift from the Eli Lilly Co. by courtesy of Dr. Hosley. Proinsulin was a gift from Dr. N. Yanaihara of Shizuoka College of Pharmacy, Shizuoka, Japan. Crystalline porcine glucagon was purchased from Novo Industry, Copenhagen, Denmark. Somatomedin-A (STE-147-3) was a gift from Dr. K. Takano of Tokyo Womens Medical College, Tokyo, Japan. Human growth hormones (hGH, NIH-HS-2160) were supplied by NIAMDD. Synthetic $\beta^{1-24}$ ACTH was purchased from Daiichi Pharmaceutical Co., Tokyo, Japan.

\section{Other Materials}

$\mathrm{Na}^{125} \mathrm{I}, \mathrm{Na}^{131} \mathrm{I}$ were purchased from the New England Nuclear Co.; bovine serum albumin (BSA; fraction V) from Armour and Co.; lactoperoxidase and human gamma globulin (fraction II) from Calbiochem.; Triton X-100 from Packard; polyethylene glycol (Carbowax 6000) from Koso Chemical Co., Tokyo; neuraminidase (from cl. perfringens), phospholipase A (from vipera russelli), trypsin (from bovine pancreas) and trypsin inhibitor (from soybean) from Sigma Chemical Co. "Combithek" protein markers for molecular weight determinations were obtained from Boehringer Mannheim. Thyroglobulin was purchased from Sigma Chemical Co. "Ampholine" carrier ampholytes were obtained from LKB Produkter AB, Sweden. Superfine Sephadex G-75 
"Ultrodex" and "Con A-Sepharose" concanavalin A covalently bound Sepharose 4B were purchased from Pharmacia, Sweden. Other chemicals were of reagent grade.

\section{Iodination of Insulin}

Porcine insulin was iodinated by lactoperoxidase as described previously [15] and separated from both free ${ }^{125} \mathrm{I}$ and damaged hormone by sequential chromatography on Sephadex G-25 and cellulose powder (Whatman CF-11). The specific activity of the ${ }^{125} \mathrm{I}-$ insulin was $150-200 \mu \mathrm{ci} / \mu \mathrm{g}$. At least $95 \%$ of radioactivity was precipitated by $10 \%$ trichloracetic acid (TCA), and more than $90 \%$ was precipitated by excess insulin antibody. The concentration of $\left[{ }^{125} \mathrm{I}\right]$ iodoinsulin was radioimmunoassayed using $\left[{ }^{131} \mathrm{I}\right]$ iodoinsulin as previously described [16].

\section{Preparation of Crude Membrane Fraction}

The crude membrane fraction was prepared from guinea pig kidney according to the method of Tsushima and Friesen [17]. Fresh or frozen kidneys thawed on ice, were minced, rinsed once in icecold $0.3 \mathrm{~mol} / 1$ sucrose, and homogenized in $5 \mathrm{vol}(\mathrm{w} / \mathrm{v})$ of $0.3 \mathrm{~mol} / \mathrm{l}$ sucrose with a Brinkman Polytron PT-10 (setting of 7) for $60 \mathrm{sec}$. The homogenate was centrifuged at $4^{\circ} \mathrm{C}$ for $15 \mathrm{~min}$ at $600 \times \mathrm{g}$, after which the supernatent was centrifuged at $15,000 \times \mathrm{g}$ for 20 $\mathrm{min}$. The $15,000 \times \mathrm{g}$ supernatant was then centrifuged at 100,000 $\times \mathrm{g}$ for $90 \mathrm{~min}$ to yield a microsomal membrane pellet, which was suspended by hand homogenization in a $0.05 \mathrm{~mol} / \mathrm{l}$ Tris- $\mathrm{HCl}$ buffer, $\mathrm{pH} 7.6$, and recentrifuged at $100,000 \times \mathrm{g}$ for $60 \mathrm{~min}$. The pellet (the "particulate fraction") was frozen and stored at $-20^{\circ} \mathrm{C}$. The final protein concentration was about $6 \mathrm{mg} / \mathrm{ml}$. Protein concentration was determined by the method of Lowry et al. [18].

\section{Solubilization of Crude Membrane Fractions}

Solubilized insulin binding and degrading activities were obtained as previously described [7]. Triton X-100, with a final concentration of $1 \%(\mathrm{v} / \mathrm{v})$, was added to the particulate fraction, and the mixture was incubated and stirred for $20 \mathrm{~min}$ at room temperature. The suspension was then centrifuged for $90 \mathrm{~min}$ at $200,000 \times \mathrm{g}$. The resultant supernatant was stored in small aliquots at $-20^{\circ} \mathrm{C}$ until use as the solubilized fraction. Under these conditions more than $80 \%$ of the total binding activity was present in this fraction.

\section{Standard Membrane Binding Assay}

1) Particulate Membrane Receptor: The particulate fraction (approximately $100-150 \mu \mathrm{g}$ protein/tube) and ${ }^{125} \mathrm{I}$-insulin $(0.1 \mathrm{ng} /$ $\mathrm{ml}$ ) were incubated with and without various concentrations of unlabelled insulin and other test substances in $12 \times 75 \mathrm{~mm}$ glass tubes at $4^{\circ} \mathrm{C}$ for $16-20 \mathrm{~h}$. Incubations were performed in 0.05 $\mathrm{mol} / 1$ Tris- $\mathrm{HCl}$ buffer at $\mathrm{pH} 7.6$ with $0.01 \mathrm{~mol} / 1 \mathrm{MgCl}_{2}$ and $0.1 \mathrm{~g} /$ $100 \mathrm{ml} \mathrm{BSA}$; incubation volume, $1.0 \mathrm{ml}$. After incubation, the samples were centrifuged at $1,500 \times \mathrm{g}$ for $30 \mathrm{~min}$. The supernatant was removed and the pellet counted in a gamma counter. All data were corrected for nonspecific binding by subtracting the amount of radioactivity remaining bound in the presence of $25 \mu \mathrm{g} /$ $\mathrm{ml}$ porcine insulin from the amount of radioactivity at all other insulin concentrations.

2) Solubilized Receptor: Fifty $\mu \mathrm{l}(50-80 \mu \mathrm{g})$ of solubilized receptor was incubated in the same conditions described above. The receptor bound hormone was selectively precipitated by polyethylene glycol as follows [7]. At the end of incubation, $0.5 \mathrm{ml}$ of chilled $0.3 \mathrm{~g} / 100 \mathrm{ml}$ human gamma globulin (final concentration, $0.05 \mathrm{~g} / 100 \mathrm{ml}$ ) was added to the tubes placed in ice. After the addition of $1.5 \mathrm{ml}$ of cold $22 \%(\mathrm{w} / \mathrm{v})$ polyethylene glycol, the tubes were vigorously mixed and iced for $20 \mathrm{~min}$. The samples were then centrifuged at $1,500 \times \mathrm{g}$ for $30 \mathrm{~min}$. The resultant supernatant was removed and the pellet counted. Specific binding was determined by the same method as for the particulate membrane. In our assay conditions, concentrations of Triton X-100 greater than $0.2 \%(\mathrm{v} / \mathrm{v})$ in the assay mixture were found to result in a significant inhibition of insulin binding. Therefore, Triton extracts of membranes were diluted so that the final concentration of the detergent was less than $0.2 \%$, and usually less than $0.0125 \%$.

\section{Insulin Degradation Study}

Degradation of ${ }^{125}$ I-insulin exposed to the membrane fraction (particulate or solubilized), was estimated by measuring the amount of radioactive material that could be precipitated with $10 \%$ trichloracetic acid (TCA). ${ }^{125} \mathrm{I}$-insulin $(0.1 \mathrm{ng} / \mathrm{ml})$ was incubated with particulate fraction at $37^{\circ} \mathrm{C}$ for $120 \mathrm{~min}$ in the same buffer as used in the binding assays. After incubation, the assay mixture was centrifuged for two min at $10,000 \times \mathrm{g}$. Aliquots of the supernatant were precipitated by $20 \%$ TCA (final concentration $10 \%$ ). In the case of solubilized fractions, aliquots of the incubation mixture were precipitated directly by TCA. Both precipitated mixtures were then centrifuged and the radioactivity of the pellets counted. Under the experimental conditions, the $\mathrm{pH}$ (7.1-7.8) of the incubation medium and the concentration of TCA (final $5-10 \%$ ) had little effect on the results. In some experiments, to cancel the effect of protein concentration and Triton X-100 on the TCA-precipitation, the degrading activity was expressed as follows:

Degrading activity $(\%)=$

$100-\left(\frac{\text { precipitated radioactivity at } 120 \mathrm{~min}}{\text { precipitated radioactivity at } 0 \mathrm{~min}}\right) \times 100$

The degrading activity of control tubes incubated in the same manner except without membrane fractions was always below $4 \%$.

\section{Sepharose 6B Chromatographic Procedure}

Gel chromatography used to determine the Stokes radius of the insulin receptor, was performed on a Sepharose $6 \mathrm{~B}$ column. A small aliquot of the solubilized insulin receptor $(4 \mathrm{mg} / \mathrm{ml})$ was preincubated with ${ }^{125} \mathrm{I}$-insulin as described above. After the incubation, $0.5 \mathrm{ml}$ of the incubation mixture was applied to a Sepharose $6 \mathrm{~B}$ column $(1 \times 87 \mathrm{~cm})$ previously equilibrated with $0.05 \mathrm{~mol} / \mathrm{l}$ Tris- $\mathrm{HCl}$ buffer, $\mathrm{pH} 7.6$, with $0.1 \%$ (v/v) Triton-X at $4^{\circ} \mathrm{C}$. A control incubation mixture to which excess $(25 \mu \mathrm{g} / \mathrm{ml})$ unlabelled insulin had been added was similarly fractionated. Flow rate was $2.5 \mathrm{ml} / \mathrm{h}$. The radioactivity of $1 \mathrm{ml}$ of each eluate was counted. Alternatively, $0.5 \mathrm{ml}$ of the solubilized insulin receptor was concentrated to $14 \mathrm{mg} / \mathrm{ml}$ of protein by using ultrafiltration membranes ["Diaflo"PM-30 (Amicon)] and fractionated on the same column. One $\mathrm{ml}$ fractions of each eluate were then assayed for insulin binding and degrading activity. Insulin degrading activity was expressed as \% degrading activity per $400 \mu \mathrm{l}$ samples as defined above. The column used in both cases was calibrated with dextran blue 2,000, thyroglobulin, ferritin, catalase, bovine serum albumin and $\mathrm{Na}^{125} \mathrm{I}$. The gel filtration data are expressed in terms of Kav, defined as Kav $=(\mathrm{Ve}-\mathrm{Vo}) /(\mathrm{Vt}-\mathrm{Vo})$ where $\mathrm{Ve}$ is the elution volume corresponding to the peak concentration of the solute, Vo is the void volume of the column as determined by the appearance of dextran blue, and Vt is the total liquid volume as determined by $\mathrm{Na}^{125} \mathrm{I}$. 


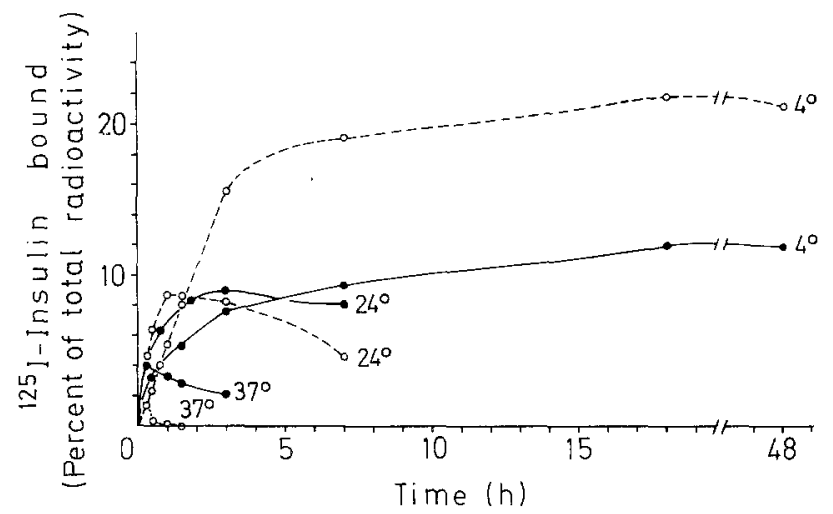

Fig. 1. Time dependence of the specific binding of ${ }^{125} \mathrm{I}$-insulin to guinea pig kidney particulate (-- - ) and solubilized fractions (--O---) at various temperatures. Particulate and solubilized fractions $(50 \mu \mathrm{g} / \mathrm{tube})$ were incubated at the indicated temperature in $0.05 \mathrm{~mol} / \mathrm{l}$ Tris- $\mathrm{HCl}$ buffer containing $0.01 \mathrm{~mol} / 1 \mathrm{MgCl}_{2}, 0.1 \mathrm{~g} /$ $100 \mathrm{ml} \mathrm{BSA}$ and $0.1 \mathrm{ng} / \mathrm{ml}^{125} \mathrm{I}$-insulin $\mathrm{pH}$ 7.6. Specific binding was determined as described in Materials and Methods and presented as $\%$ binding of total radioactivity per $50 \mu \mathrm{g}$ protein. The values presented are from a representative experiment. Similar results were obtained in two other experiments

\section{Isoelectric Focusing}

Isoelectric focusing between $\mathrm{pH} 3.5$ and $\mathrm{pH} 10$ was carried out by preparative flat-bed isoelectric focusing in a granulated gel using the LKB 2117 "Multiphor" (LKB Produkter, AB, Sweden) (LKB application note 198). Five $\mathrm{ml}$ of the solubilized fraction (protein $4-5 \mathrm{mg} / \mathrm{ml}$ ) were diluted with $90 \mathrm{ml}$ of distilled water containing $0.11 \%(\mathrm{v} / \mathrm{v})$ of Triton X-100 and then $5 \mathrm{ml}$ of "Ampholine" carrier ampholytes (LKB 1809-101, pH 3.5-10) were added. If a slight precipitate formed at this stage, it was removed by centrifugation at $10,000 \times \mathrm{g}$. Five $\mathrm{g}$ of Sephadex $\mathrm{G}-75$ superfine (Ultrodex, Pharmacia) was slowly added to the mixture and the suspension poured on a glass plate and placed in the "Multiphor". Focusing was carried out at $8 \mathrm{~W}$ for $12 \mathrm{~h}$ at $4^{\circ} \mathrm{C}$. The initial voltage was $300 \mathrm{~V}$ and current, $27 \mathrm{~mA}$. The gel bed was then sectioned into 30 fractions with a grid. The granulated gels of each fraction were eluted with $1.0 \mathrm{ml}$ distilled $\mathrm{H}_{2} \mathrm{O}$. After measurement of $\mathrm{pH}$, each fraction was eluted further with $2.0 \mathrm{ml} 0.1 \mathrm{~mol} / \mathrm{l}$ Tris-HCl buffer, $\mathrm{pH} 7.6$, containing $0.1 \%(\mathrm{v} / \mathrm{v})$ Triton. Samples $(100 \mu \mathrm{l})$ of these eluted fractions were assayed for the binding studies and $200 \mu \mathrm{l}$ samples for degradation studies. Insulin degrading activity was expressed as \% degrading activity per $200 \mu \mathrm{l}$ samples as defined above. When these eluted fractions were diluted ten times with $0.05 \mathrm{~mol} / \mathrm{l}$ Tris- $\mathrm{HCl}$ buffer, $\mathrm{pH} 7.6$, they had no effect on the $\mathrm{pH}$ of the assay mixture in the binding and degradation studies. In some cases, a slight precipitate formed in the eluted fractions especially the acidic ones. These precipitates were removed by centrifugation and the supernatants assayed. In the experiments, the pIs of insulin binding and degrading activities were not influenced by these precipitates.

\section{Concanavalin A-Agarose Affinity Chromatography}

Two $\mathrm{ml}$ of solubilized fraction (protein $4 \mathrm{mg} / \mathrm{ml}$ ) in Triton X-100 was allowed to run through $4 \mathrm{ml}$ of packed concanavalin $\mathrm{A}$ coupled agarose, "Con A - Sepharose" (Pharmacia), in a column (1 $\times 10 \mathrm{~cm}$ ), which was equilibrated at $4^{\circ} \mathrm{C}$ for $3 \mathrm{~h}$ with $0.05 \mathrm{~mol} / \mathrm{l}$

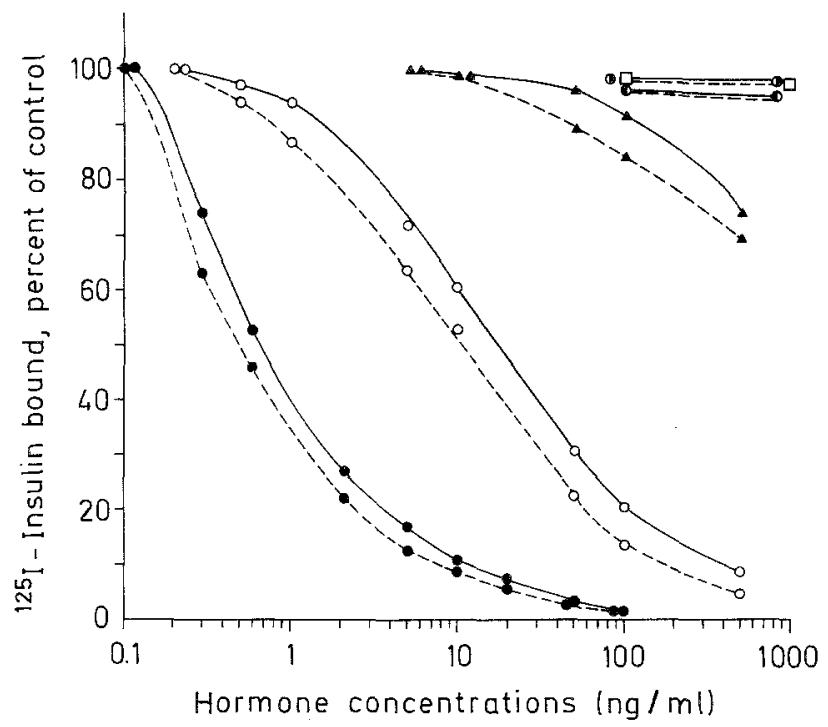

Fig. 2. Competition for ${ }^{125} \mathrm{I}$-insulin binding by insulin, insulin analogues and other polypeptide hormones. ${ }^{125} \mathrm{I}$-insulin $(0.1 \mathrm{ng} /$ $\mathrm{ml}$ ) was incubated at $4^{\circ} \mathrm{C}$ for $18 \mathrm{~h}$ with $100 \mu \mathrm{g}$ of particulate (-) or solubilized fractions (-..--) and increasing amounts of the test substances. Specific binding was determined as described in Materials and Methods. Results are expressed as \% specific binding found in the presence of only labelled insulin, which was $18.7 \%$ of total radioactivity in the particulate receptor and $34.7 \%$ in the solubilized receptor. The values presented are from a representative experiment. Similar results were obtained in another similar experiment. insulin, O proinsulin, $\triangle$ Somatomedin-A, $\mathbf{h G H}$, $\square$ ACTH, G Glucagon

Tris- $\mathrm{HCl}$ buffer, $\mathrm{pH} 7.6$, containing $0.1 \%(\mathrm{v} / \mathrm{v})$ Triton $\mathrm{X}-100$. The flow rate was about $10 \mathrm{ml} / \mathrm{h}$. Ten bed volumes of the same buffer were used to wash the column until no protein of insulin binding activity were eluted. Elutions were achieved with $10 \mathrm{ml} 0.3 \mathrm{~mol} / \mathrm{l}$ $\alpha$-methyl-D-glucoside and $20 \mathrm{ml} \quad 0.3 \mathrm{~mol} / \mathrm{l} \quad \alpha$-methyl-D-mannoside in the same buffer. Eluate was collected in $1 \mathrm{ml}$ fractions. The column flow was stopped for $1 \mathrm{~h}$ at room temperature after the addition of the each eluting buffer. Samples $(100 \mu l)$ of each fraction were assayed for insulin binding and degradation studies.

\section{Results}

\section{Binding of ${ }^{125} I$-Insulin to Particulate and Solubilized Fractions}

The time course of the binding of ${ }^{125}$ I-insulin to particulate and solubilized fraction is shown in Fig. 1. Incubation of the particulate $(50 \mu \mathrm{g}$ protein/tube) and the solubilized fractions (50 $\mu \mathrm{g}$ protein/tube) with labelled insullin $(0.1 \mathrm{ng} / \mathrm{ml})$ for $18 \mathrm{~h}$ at $4^{\circ} \mathrm{C}$ led to a steady state of specific binding which was about $12 \%$ and $22 \%$ of the total radioactivity respectively for $50 \mu \mathrm{g}$ protein of the two fractions. Specific binding was constant from 18 to $48 \mathrm{~h}$, suggesting that there was little or no degradation of the labelled insulin during this period. On the other hand, incubation at 24 and $37^{\circ} \mathrm{C}$ resulted in a lower specific binding 
Table 1. Effect of various protein-denaturing reagents on ${ }^{125} \mathrm{I}-$ insulin binding to kidney particulate and solubilized fractions

\begin{tabular}{llcc}
\hline & & \multicolumn{2}{c}{$\begin{array}{l}\text { Specific binding of } \\
125\end{array}$} \\
\cline { 3 - 4 } Denaturant & & $\begin{array}{l}\text { Particulate } \\
\text { fractions }\end{array}$ & $\begin{array}{l}\text { Solubilized } \\
\text { fractions }\end{array}$ \\
\hline None & & 100 & 100 \\
Sodium dodecyl sulphate & $1 \mathrm{~g} / \mathrm{l}$ & $5 \pm 2$ & $13 \pm 4$ \\
Urea & $5 \mathrm{~mol} / 1$ & $4 \pm 1$ & $3 \pm 1$ \\
Guanidine-HCl & $4 \mathrm{~mol} / \mathrm{l}$ & $<1$ & $<1$ \\
Acetic acid & $1 \mathrm{~mol} / 1$ & $4 \pm 1$ & $<1$ \\
NaCl & $2 \mathrm{~mol} / 1$ & $64 \pm 6$ & $76 \pm 4$ \\
Dithiothreitol & $1 \mathrm{~m} \mathrm{~mol} / 1$ & $77 \pm 4$ & $73 \pm 4$ \\
N-Ethylmaleimide & $1 \mathrm{~m} \mathrm{~mol} / 1$ & $97 \pm 2$ & $108 \pm 6$ \\
\hline
\end{tabular}

Kidney particulate and solubilized fractions (final concentration $1 \mathrm{mg} / \mathrm{ml}$ ) were incubated in $0.05 \mathrm{~mol} / 1$ Tris- $\mathrm{HCl}$ buffer, $\mathrm{pH} 7.6$ with or without $0.1 \%(\mathrm{v} / \mathrm{v})$ Triton for $60 \mathrm{~min}$ at $24^{\circ} \mathrm{C}$ with the indicated final concentration of the various reagents shown above. After incubation, all samples were dialyzed against $0.05 \mathrm{~mol} / 1$ Tris-HCl buffer, $\mathrm{pH} 7.6$, with or without $0.1 \%(\mathrm{v} / \mathrm{v})$ Triton at $4^{\circ} \mathrm{C}$ for $24 \mathrm{~h}$. After dialysis, 200-300 $\mu \mathrm{l}$ samples of the aliquots were assayed for insulin binding by the standard assay method. Data are expressed as mean \pm SEM of three experiments

and a shorter duration of the steady state. Incubations for insulin binding in further experiments were therefore performed at $4^{\circ} \mathrm{C}$ for $16-20 \mathrm{~h}$.

The amount of ${ }^{125} \mathrm{I}$-insulin bound at the steady state was proportional to the concentration of the particulate or solubilized fraction at least up to a concentration of $150 \mu \mathrm{g} /$ tube (data not shown). In most studies, less than $100 \mu \mathrm{g}$ of protein/tube were used for the insulin binding incubations.

The specificity of the binding of ${ }^{125} \mathrm{I}$-insulin to the solubilized fractions was compared to that of the particulate fractions (Fig. 2). Increasing concentrations of unlabelled insulin inhibited ${ }^{125} \mathrm{I}$-insulin binding to both fractions in a similar manner. About half of ${ }^{125} \mathrm{I}-$ insulin specific binding was displaced by $0.6 \mathrm{ng} / \mathrm{ml}$ insulin. Porcine proinsulin showed significant competition for both types of receptor. On a molar basis, porcine proinsulin was approximately $6 \%$ as potent as porcine insulin. Somatomedin-A was far less potent than porcine insulin. Glucagon, synthetic $\beta^{1-24} \mathrm{ACTH}$ and hGH did not cause any significant displacement. The hormonal specificity of the particulate receptor was similar to that of the solubilized receptor.

\section{Effect of Enzymes and Protein-Denaturing Reagents on ${ }^{125}$ I-insulin Binding}

In the guinea pig kidney particulate fraction, insulin binding was destroyed by low concentrations of tryp$\sin (2 \mu \mathrm{g} / \mathrm{ml})$, while neuraminidase $(20 \mu \mathrm{g} / \mathrm{ml})$ and
Table 2. Effect of various reagents on ${ }^{125} \mathrm{I}$-insulin degradation by kidney particulate and solubilized fractions

\begin{tabular}{llll}
\hline & & \multicolumn{2}{c}{$\begin{array}{l}{ }^{125} \text { I-insulin degrading } \\
\text { activity (\%) }\end{array}$} \\
\cline { 2 - 4 } Reagents & & $\begin{array}{l}\text { Particulate } \\
\text { fractions }\end{array}$ & $\begin{array}{c}\text { Solubilized } \\
\text { fractions }\end{array}$ \\
\hline Control & & 100 & 100 \\
Glutathione & $m$ mol/l & & \\
N-Ethylmaleimide & 1 & $159 \pm 8$ & $130 \pm 8$ \\
EDTA & 5 & $12 \pm 3$ & $6 \pm 3$ \\
& 5 & $2 \pm 1$ & $2 \pm 1$ \\
$\beta^{1-24}$ ACTH & $4 g / m l$ & $40 \pm 5^{\mathrm{a}}$ & $49 \pm 4^{\mathrm{a}}$ \\
Glucagon & 1 & $94 \pm 1$ & $94 \pm 1$ \\
Proinsulin & 1 & $92 \pm 1$ & $92 \pm 1$ \\
\hline
\end{tabular}

Particulate and solubilized fractions $(50 \mu \mathrm{g} /$ tube) from guinea pig kidney were incubated at $37^{\circ} \mathrm{C}$ for $120 \mathrm{~min}$ in $0.05 \mathrm{~mol} / 1$ Tris- $\mathrm{HCl}$ buffer, $\mathrm{pH} 7.6$, containing $0.01 \mathrm{~mol} / 1 \mathrm{MgCl}_{2}, 0.1 \mathrm{~g} / 100 \mathrm{ml} \mathrm{BSA}$ and $0.1 \mathrm{ng} / \mathrm{ml}^{125} \mathrm{I}$-insulin with or without the various reagents listed above. TCA precipitable radioactivity was determined as described in Materials and Methods. Data are expressed as mean

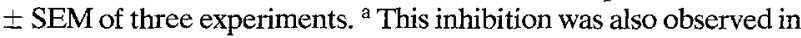
the same incubation buffer without $0.01 \mathrm{~mol} / \mathrm{I} \mathrm{MgCl}_{2}$

phosopholipase A $(50 \mu \mathrm{g} / \mathrm{ml})$ had no effect. The same was observed for the solubilized fractions. The effect of various protein-denaturing reagents on ${ }^{125} \mathrm{I}-$ insulin binding to the particulate and solubilized fractions also was studied (Table 1). The insulin binding activity of the particulate and solubilized fractions was almost completely destroyed by incubation with $5 \mathrm{~mol} / \mathrm{l}$ urea or $4 \mathrm{~mol} / \mathrm{l}$ guanidine- $\mathrm{HCl}$ for $60 \mathrm{~min}$ at $24^{\circ} \mathrm{C}$. Exposure of the receptors to $1 \mathrm{~mol} / 1$ acetic acid also resulted in a significant loss of binding activity. $2 \mathrm{~mol} / 1 \mathrm{NaCl}$ supressed the insulin binding to a lesser extent. Although $1 \mathrm{~m} \mathrm{~mol} / \mathrm{l}$ dithiothreitol caused a decrease in specific binding of insulin, $1 \mathrm{~m} \mathrm{~mol} / 1 \mathrm{~N}$ ethylmaleimide had no effect.

\section{Insulin Degrading Activity of Particulate and Solubilized Fractions}

The time course of insulin degradation by the two types of receptor preparation at various temperatures is shown in Fig. 3. It is evident that the integrity of ${ }^{125}$ I-insulin, judged by TCA precipitability, remained unchanged for two hours at the lower temperature, whereas at 24 and $37^{\circ} \mathrm{C}$ significant degradation occurred. The insulin degrading activity of the solubilized fractions per unit of protein was greater than that of the particulate fractions. The amount of ${ }^{125} \mathrm{I}$ insulin degraded was proportional to the concentration of the receptor preparations up to $25 \mu \mathrm{g} /$ tube (data not shown). The effect of various reagents and hormones on ${ }^{125} \mathrm{I}$-insulin degradation was studied 
(Table 2). Glutathione stimulated the insulin degrading activity of particulate fractions, while $\mathrm{N}$-ethylmaleimide, EDTA and proinsulin inhibited the degradation. Similar effects were observed for the solubilized fractions.

\section{Gel Filtration and Determination of Stokes Radius}

An aliquot of the solubilized fractions was incubated with ${ }^{125} \mathrm{I}$-insulin and the incubation mixture fractionated on Sepharose 6B. The distribution of radioactivity is shown in Fig. 4. The radioactive peak at Fraction 36 ( Kav $=0.30)$ represents the ${ }^{125}$ I-insulinreceptor complex since this peak disappeared when incubation was carried out in the presence of excess cold insulin. The radioactive peak at Fraction 58 $(\mathrm{Kav}=0.78)$ and the small peak at Fraction 68 represent ${ }^{125}$ I-insulin and ${ }^{125}$ I respectively.

An aliquot of concentrated solubilized fraction was fractionated on the same column, and the fractions assayed for insulin binding and degrading activity. The peak of insulin binding activity eluted at Fraction $36(\mathrm{Kav}=0.30)$ and was separate from that of degrading activity (Fraction 41, Kav $=0.41$ ) (Fig. 5). Based on the elution patterns of proteins of known molecular size, the Stokes radii for insulin binding protein and degrading activity were estimated to be $73 \AA$ and $54 \AA$ respectively. Similar results were obtained in three other experiments. (73 $\pm 2 \AA$ and $54 \pm 1 \AA$ respectively, mean $\pm \mathrm{SEM}, \mathrm{n}=4)$.

\section{Isoelectric Focusing}

When an aliquot of the solubilized receptor was isoelectrically focused in a flat-bed gel with "Ampholine" of $\mathrm{pH} 3.5-10$, peak activity was recovered at Fraction 13 for insulin binding and at Fraction 11 for insulin degradation (Fig. 6). Thus, the $\mathrm{pI}$ of the insulin binding activity was near 5.6 (5.58 \pm 0.06 , mean $\pm S E M, n=5$ ). Similar values for the $\mathrm{pI}$ of the insulin binding activity $(5.5-5.8)$ were obtained in experiments using narrow ranged $(\mathrm{pH}$ 3.5-8) "Ampholine". The $\mathrm{pI}$ of the insulin degrading activity was near 5.2 (5.22 \pm 0.04 , mean \pm SEM, $n$ $=5)$. In addition, a small peak of insulin degrading activity with a $\mathrm{pI}$ near $4.6(4.62 \pm 0.03$, mean \pm $\mathrm{SEM}, \mathrm{n}=5$ ) was detected at Fraction 7 .

\section{Concanavalin A-Agarose Affinity Chromatography}

When $2 \mathrm{ml}$ of the solubilized crude membrane fractions was applied to a $4 \mathrm{ml}$ column of concanavalin A-agarose, more than $98 \%$ of the insulin binding activity was adsorbed to the column. On the other hand, about $94 \%$ of insulin degrading activity was

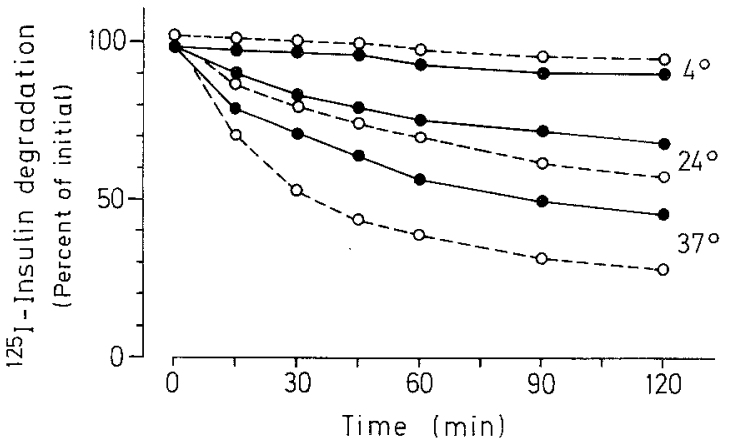

Fig. 3. Time course of ${ }^{125} \mathrm{I}$-insulin degradation by guinea pig kidney particulate (- - ) and solubilized fractions (---O---) at various temperatures. Particulate and solubilized fractions $(100 \mu \mathrm{g} /$ tube) were incubated at the indicated temperature in $0.05 \mathrm{~mol} / \mathrm{l}$ Tris-HCl buffer, $\mathrm{pH} 7.6$, containing $0.01 \mathrm{~mol} / 1 \mathrm{MgCl}_{2}, 0.1 \mathrm{~g} /$ $100 \mathrm{ml} \mathrm{BSA}$ and $0.1 \mathrm{ng} / \mathrm{ml}{ }^{125} \mathrm{I}$-insulin. At each time, $10 \%$ TCA precipitable radioactivity was determined as described in Materials and Methods. Data are expressed as percentage of the TCA precipitable radioactivity at 0 time. The values presented are from a representative experiment. Similar results were obtained in two other experiments

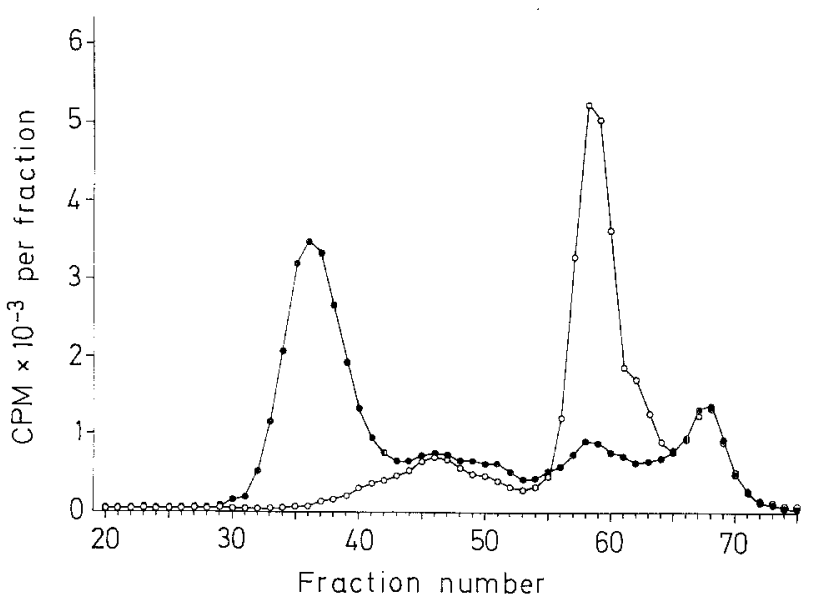

Fig. 4. Sepharose 6B chromatography of solubilized insulin receptor of guinea pig kidney. ${ }^{125} \mathrm{I}$-insulin $(47000 \mathrm{cpm})$ was incubated with $400 \mu \mathrm{g}$ of solubilized receptor at $4^{\circ} \mathrm{C}$. After $18 \mathrm{~h}, 0.5 \mathrm{ml}$ of the incubation mixture was chromatographed on a Sepharose $6 \mathrm{~B}$ column $(1 \times 87 \mathrm{~cm})$ as described in Materials and Methods. Fractions of $1 \mathrm{ml}$ were collected and counted. Dextran blue appears at Fraction 22. The radioactive peak at Fraction $36(\mathrm{Kav}=0.30)$ represents the hormone-receptor complex and that at Fraction 58 $(\operatorname{Kav}=0.78)$ is ${ }^{125}$ I-insulin. The small radioactive peak at Fraction 68 represents ${ }^{125}$ I. The small radioactive hump at Fraction 45 was essentially unchanged in the presence of native insulin $(25 \mu \mathrm{g} /$ $\mathrm{ml})$ or in the absence of membrane extract. Incubations in the absence $(\bullet)$ and the presence $(0)$ of unlabelled insulin $(25 \mu \mathrm{g} / \mathrm{ml})$. The values presented are from a representative experiment. Similar results were obtained in two other experiments

not absorbed. About $25 \%$ and $30 \%$ of insulin binding activity could be eluted with $0.3 \mathrm{~mol} / 1 \alpha$-methyl glucoside and $0.3 \mathrm{~mol} / \mathrm{l} \alpha$-methyl-mannoside respectively, while only a little insulin degrading activity was eluted with these sugars. 


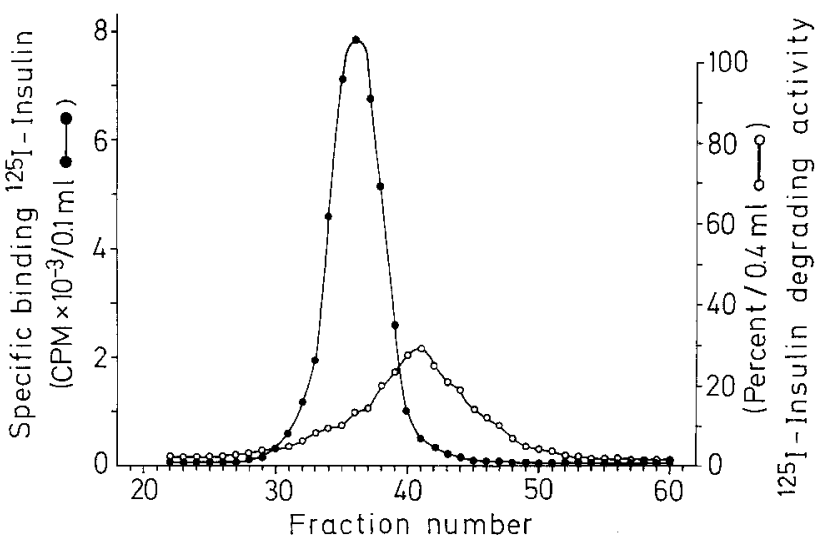

Fig. 5. Sepharose 6B chromatography of the solubilized membrane fractions from guinea pig kidney. $0.5 \mathrm{ml}$ of the concentrated solubilized membrane fractions $(14 \mathrm{mg}$ protein $/ \mathrm{ml}$ ) was chromatographed on the same Sepharose 6B column as described for Fig. 4. One $\mathrm{ml}$ fractions were collected, and aliquots of $0.1 \mathrm{ml}$ and $0.4 \mathrm{ml}$ were assayed for insulin binding activity (•-•) and insulin degrading activity $\left(\mathrm{O}_{-} \mathrm{O}\right)$ respectively. Non-specific binding was subtracted as described in Materials and Methods. Total radioactivities used in binding assay were $24,000 \mathrm{cpm}$. The peak of insulin binding activity occurred at Fraction $36(\mathrm{Kav}=0.30)$, whereas, the peak of insulin degrading activity was present at Fraction 41 $(\mathrm{Kav}=0.41)$. The values presented are from a representative experiment. Similar results were obtained in three other experiments

\section{Discussion}

Insulin may have some role in the metabolism of the kidney. Thus, insulin effects on renal electrolyte transport have been postulated [19]. In addition, about $30 \%$ of the insulin delivered to the kidney is known to be removed by this organ [20], and the kidney may be a major site for the uptake and degradation of insulin. Further by in vitro studies, insulin is known to bind to mammalian kidney $[11,14,15,21]$ and also to be degraded by the tissue $[14,22,23]$.

Various tissues of guinea pigs, particularly the kidney have been shown to bind higher amounts of insulin than tissues of other animals [11]. In this paper, we studied the insulin binding of both particulate $(100,000 \times \mathrm{g}$ pellet $)$ and solubilized fractions from guinea pig kidney. The insulin binding to the particulate fractions was time, temperature (Fig. 1) and membrane concentration dependent. Insulin, insulin analogues and other polypeptide hormones inhibited the insulin binding in direct proportion to their insulin biological potency (Fig. 2) as previously described $[15,24]$. The effects of enzyme digestion and protein-denaturing agents (Table 1 ) were very similar to the results that have been reported for insulin receptor in liver $[25,26]$ and placenta $[8,9]$. All these results strongly suggest that the particulate fractions from guinea pig kidney contain a biologi-

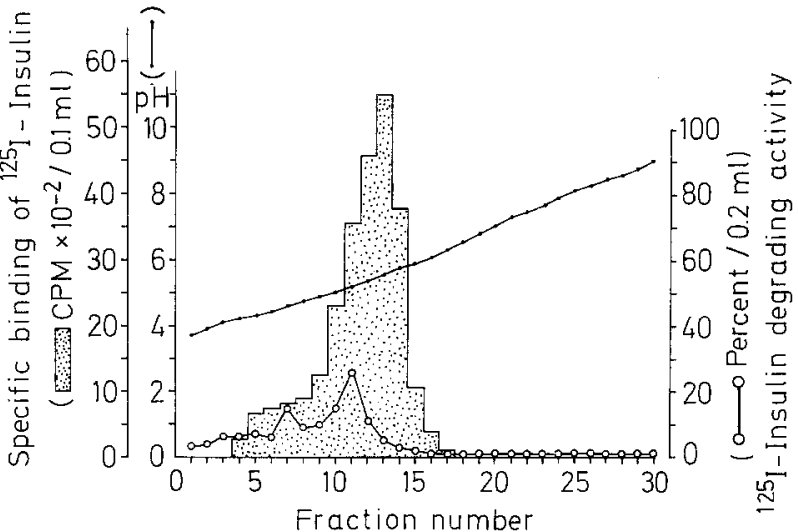

Fig. 6. Preparative flat-bed isoelectric focusing of the solubilized crude membrane fractions from guina pig kidney. $5 \mathrm{ml}$ of the Triton-extract $(4-5 \mathrm{mg}$ of protein per $\mathrm{ml}$ ) was focused in a flat-bed gel with $\mathrm{pH} 3.5-10$ "Ampholine" at $8 \mathrm{~W}$ for $12 \mathrm{~h}$ at $4^{\circ} \mathrm{C}$. After the focusing, the gel bed was fractionated as described in Materials and Methods. Aliquots of 0.1 and $0.2 \mathrm{ml}$ of each fraction were assayed for insulin binding activity (shaded area) and insulin degrading activity $(\mathrm{O}-\mathrm{O})$ respectively. The peak of insulin bind-

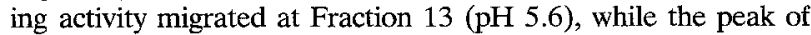
insulin degrading activity was present at Fraction 11 ( $\mathrm{pH} 5.2$ ). The values presented are from a representative experiment. Similar results were obtained in four other experiments

cally important insulin receptor. Furthermore, as shown in Figs. 1 and 2 and Table 1, the solubilized binding sites from these particulate fractions, retain the same characteristics as those of the particulate membranes themselves, indicating that Triton extraction does not cause any major change in the properties of the insulin receptor.

Both the solubilized insulin receptors of guinea pig kidney membrane fractions and their complex with ${ }^{125} \mathrm{I}$-insulin appear as a single peak on Sepharose $6 \mathrm{~B}$ gel filtration in Fraction $36(\mathrm{Kav}=0.30)$ with a Stokes radius of $73 \AA$ (Figs. 4 and 5). This value for the solubilized insulin receptor from guinea pig kidney is similar to the values for the insulin receptors of rat liver and avian erythrocytes [26, 10]. It is not possible to determine the molecular weight of the insulin receptor by gel filtration alone, since it is well known that the elution behaviour of macromolecules correlates with the Stokes radius of the protein rather than with its molecular weight [27]. However, the coincidence of the Stokes radius of both the kidney and liver insulin receptors indicates that the molecular weight of the kidney insulin receptor is also about 300,000 [26]. This estimate is also identical to that obtained for the solubilized insulin receptors from placenta [9] and avian erythrocytes [10]. On the other hand, the result of isoelectric focusing indicates that the pI of the solubilized insulin receptor from 
guinea pig kidney is about 5.6 (Fig. 6) which is different from the value, 4.0 , for the purified liver insulin receptor reported by Jacobs et al. [28]. Thus, compared with the solubilized insulin receptor from rat liver plasma membranes, that from guinea pig kidney has the same Stokes radius but a more alkaline pI.

It has been demonstrated that concanavalin A and wheat germ agglutinin interact with the insulin receptor in rat liver [29]. The fact that the solubilized insulin receptors from guinea pig kidney adsorb to the concanavalin A-agarose column and are eluted with the specific simple sugars indicates that this insulin receptor also interacts with concanavalin A and may be a glycoprotein similar to the receptor in rat liver [29].

Recently, two distinct insulin binding activites have been demonstrated in solubilized fat cell membrane by using polyacrylamide gel electrophoresis [30]. As shown in Fig. 6, the fact that the binding activity of our solubilized receptor is not symmetrically distributed in isoelectric focusing also suggests that the insulin receptors are not all identical. Preliminary experiments in the narrow range $(\mathrm{pH}$ 3.5-8.0) showed another small peak of binding activity at a pI near 4.6 , which was distinguishable from that at a $\mathrm{pI}$ 5.6.

The solubilized insulin degrading activity retained the characteristics observed in the particulate fractions regarding its time, temperature and membrane concentration dependent degrading process, and its hormonal specificity as well as its susceptibility to various reagents. (Fig. 3 and Table 2). The observation that $\mathrm{N}$-ethylmaleimide inhibited and glutathione stimulated the degradation reaction are consistent with data reported by Freychet et al. [12] for liver membrane insulin degrading activity. The latter result is also compatible with observations described for glutathione insulin transhydrogenase [31]. As glutathione insulin transhydrogenase is known to be present in large amounts in $100,000 \times \mathrm{g}$ pellets of rat kidney $[23,32]$ and activated by Triton X-100 [33], some part of the insulin degrading activity of our solubilized fraction may be due to this. On the other hand, this insulin degrading activity might be due to insulin protease, since the degrading activity is inhibited by N-ethylmaleimide and EDTA, and these reagents are known to inhibit the proteolytic stage of insulin degradation $[22,34]$. Therefore, it is likely that both enzymes and possibly others play a role in insulin degradation. This notion is further supported by the fact that the degrading activity is distributed over a wide range on gel filtration and that an additional small peak of degrading activity was detected on isoelectric focusing. Interestingly, Varandani [35] has reported that the $\mathrm{pI}$ of glutathione insulin trans- hydrogenase isolated from several tissues is 4.65 . Therefore, there is a possibility that a small peak of the degrading activity with a pI near 4.6 is due to this enzyme.

On gel filtration, the peak of solubilized insulin degrading activity from guinea pig kidney membrane fractions appears at Fraction $41(\mathrm{Kav}=0.41)$ with a Stokes radius of $54 \AA$ (Fig. 5). It is eluted at a different position from that of the insulin binding activity. The pI of insulin degrading activity is near 5.2 (Fig. 6) and is also clearly different from that of insulin binding activity. Furthermore, almost all of the insulin binding activity can be adsorbed to an concanavalin A-agarose column, while the majority of the insulin degrading activity is not adsorbed to this column. These results strongly suggest that the macromolecule for the insulin binding activity is not identical to that for the insulin degrading activity. They further suggest that the majority of insulin receptors do not have the insulin degrading activity. However, the possibility that a minor population of insulin receptors (pI near 4.6) also has degrading activity cannot be excluded.

Acknowledgements. The authors gratefully acknowledge the editing assistance of Dr. David M. Warshauer and also the valuable technical assistance of Ms. M. Nishihara, Ms. T. Saito, and Ms. Y. Irigaki.

\section{References}

1. Roth, J.: Peptide hormone binding to receptors: A review of direct studies in vitro. Metabolism 22, 1059-1073 (1973)

2. Freychet, P., Roth, J., Neville, D. M., Jr.: Insulin receptors in the liver: Specific binding of $\left[{ }^{125} \mathrm{I}\right]$ insulin to the plasma membrane and its relation to insulin bioactivity. Proc. Natl. Acad. Sci. USA 68, 1833-1837 (1971)

3. Cuatrecasas, P., Desbuquois, B., Krug, F.: Insulin - receptor interaction in liver cell membrane. Biochem. Biophys. Res. Commun. 44, 333-339 (1971)

4. Cuatrecasas, P.: Insulin - receptor interactions in adipose tissue cells: Direct measurement and properties. Proc. Natl. Acad. Sci. USA 68, 1264-1268 (1971)

5. Kono, T., Barham, F. W.: The relationship between the insulin - binding capacity of fat cells and the cellular response to insulin. Studies with intact and trypsin - treated fat cells. J. Biol. Chem. 246, 6210-6216 (1971)

6. Posner, B. I.: Insulin receptors in human and animal placental tissue. Diabetes 23, 209-217 (1974)

7. Cuatrecasas, P.: Isolation of the insulin receptor of liver and fat cell membranes. Proc. Natl. Acad. Sci. USA 69, 318-322 (1972)

8. Marshall, R. N., Underwood, L. E., Voina, S. J., Foushee, D. B., Van Wyk, J.J.: Characterization of the insulin and somatomedin-C receptors in human placental cell membranes. J. Clin. Endocrinol. Metab. 39, 283-292 (1974)

9. Harrison, L. C., Billington, T., East, I. J., Nichols, R. J., Clark, S.: The effect of solubilization on the properties of the insulin recepter of human placental membranes. Endocrinology 102, 1485-1495 (1978) 
10. Ginsberg, B. H., Kahn, C. R., Roth, J., De Meyts, P.: Insulininduced dissociation of its receptor into subunits: Possible molecular concomitant of negative cooperativity. Biochem. Biophys. Res. Commun. 73, 1068-1074 (1976)

11. Posner, B. I., Kelly, P. A., Shiu, R.P. C., Friesen, H. G.: Studies of insulin, growth hormone and prolactin binding: Tissue distribution, species variation and characterization. Endocrinology 95, 521-531 (1974)

12. Freychet, P., Kahn, R., Roth, J., Neville, D. M., Jr.: Insulin interactions with liver plasma membranes: Independence of binding of the hormone and its degradation. J. Biol. Chem. 247, 3953-3961 (1972)

13. Terris, S., Steiner, D. F.: Binding and degradation of ${ }^{125} \mathrm{I}$-insulin by rat hepatocytes. J. Biol. Chem. 21, 8389-8398 (1975)

14. Duckworth, W. C.: Insulin and glucagon binding and degradation by kidney cell membranes. Endocrinology 102, 1766-1774 (1978)

15. Suzuki, K., Ohsawa, N., Kosaka, K.: Radioreceptor assay for insulin. J. Clin. Endocrinol. Metab. 42, 399-402 (1976)

16. Kasuga, M., Akanuma, Y., Iwamoto, Y., Kosaka, K.: Effects of fasting and refeeding on insulin receptors and glucose metabolism in rat adipocytes. Endocrinology 100, 1384-1390 (1977)

17. Tsushima, T., Friesen, H. G.: Radioreceptor assay for growth hormone. J. Clin. Endocrinol. Metab. 37, 334-337 (1973)

18. Lowry, O. H., Rosenbrough, N. J., Fau, A. L., Randall, R. J.: Protein measurement with the Folin phenol reagent. J. Biol. Chem. 193, 265-275 (1951)

19. De Fronzo, R. A., Goldberg, M., Agus, Z. S.: The effect of glucose and insulin on renal electrolyte transport. J. Clin. Invest. 58, 83-90 (1976)

20. Chamberlain, M. H., Stimmler, L.: The renal handling of insulin. J. Clin. Invest. 46, 911-919 (1967)

21. Blanchard, R. F., Davis, P. J., Blas, S. D.: Physical characteristics of insulin receptors on renal cell membranes. Diabetes 27, 88-95 (1978)

22. Kitabchi, A. E., Stenz, F. B.: Degradation of insulin and proinsulin by various organ homogenates of rat. Diabetes $\mathbf{2 1}$, 1091-1101 (1972)

23. Varandani, P. T.: Insulin degradation. IV. Sequential degradation of insulin by rat kidney, heart and skeletal muscle homogenates. Biochim. Biophys. Acta 295, 630-636 (1973)

24. Hyodo, T., Megyesi, K., Kahn, C. R., McLean, J. P., Friesen, H. G.: Adrenocortical carcinoma and hypoglycemia: Evidence for production of nonsuppressible insulin-like activity by the tumor. J. Clin. Endocrinol. Metab. 44, 1175-1184 (1977)
25. Cuatrecasas, P.: Perturbation of the insulin receptor of isolated fat cells with proteolytic enzymes. J. Biol. Chem. 246, 6522-6531 (1971)

26. Cuatrecasas, P.: Properties of the insulin receptor isolated from liver and fat cell membranes. J. Biol. Chem. 247, 1980-1991 (1972)

27. Ackers, G. K.: Molecular exclusion and restricted diffusion processes in molecular-sieve chromatography. Biochemistry $\mathbf{3}$, 723-730 (1964)

28. Jacobs, S., Skechter, Y., Bissell, K., Cuatrecasas, P.: Purification and properties of insulin receptors from rat liver membranes. Biochem. Biophys. Res. Commun. 77, 981-986 (1977)

29. Cuatrecasas, P., Tell, G.P. E.: Insulin-like activity of concanavalin $\mathrm{A}$ and wheat germ agglutinin: Direct interactions with insulin receptors. Proc. Natl. Acad. Sci. USA 70, 485-489 (1973)

30. Krupp, M. N., Livingston, J. N.: Insulin binding to solubilized material from fat cell membranes: Evidence for two binding species. Proc. Natl. Acad. Sci. USA 75, 2593-2597 (1978)

31. Varandani, P. T.: Insulin degradation. I. Purification and properties of glutathione-insulin transhydrogenase of rat liver. Biochim. Biophys. Acta 286, 126-135 (1972)

32. Duckworth, W.C.: Insulin and glucagon degradation by the kidney. II. Characterization of the mechanisms at neutral $\mathrm{pH}$. Biochim. Biophys. Acta 437, 531-543 (1976)

33. Varandani, P. T.: Insulin degradation. V. Unmasking of glutathione-insulin transhydrogenase in rat liver microsomal membrane. Biochim. Biophys. Acta 304, 642-659 (1973)

34. Varandani, P.T., Shroyer, L.A., Nafz, M. A.: Sequential degradation of insulin by rat liver homogenates. Proc. Natl. Acad. Sci. USA 69, 1681-1684 (1972)

35. Varandani, P. T.: Mechanistic and structural aspects of GIT. In: Mechanism of oxidizing enzymes. Singer, T.P., Ondarza, R. N. (Ed), pp. 29-42. New York: Elsevier 1978

Received: January 11, 1979 ,

and in revised form: May 23, 1979

Masato Kasuga, M. D.

Third Department of Internal Medicine

Faculty of Medicine

University of Tokyo

Hongo, Tokyo

Japan 113 